\section{(e) \\ Check for updates}

Article Type: Research Paper

\title{
DOES SPIRITUALITY GIVE AN IMPACT ON THE WELL-BEING OF AN ENTREPRENEUR?
}

\author{
Wulan Wiyat Wuri*, Prima Andriani, and Radikal Yuda Utama
}

\section{OPEN}

\section{AFFILIATION:}

Universitas Gadjah Mada,

Yogyakarta. Indonesia.

\section{*CORRESPONDENCE:}

wulan.ww@gmail.com

THIS ARTICLE IS AVALILABLE IN:

http://journal.umy.ac.id/index.php/esp

DOI: $10.18196 /$ jesp.20.2.5026

\section{CITATION:}

Wuri, W. W., Andriani, P., \& Utama, Y. (2019). Does Spirituality Give an Impact on the Well-Being of an Entrepreneur?. Jurnal Ekonomi \& Studi Pembangunan, 20(2), 221-231.

\section{ARTICLE HISTORY}

Received:

24 August 2019

\section{Accepted:}

23 October 2019

\begin{abstract}
Spirituality directs individuals to be more supportive in various work activities, especially in entrepreneurship context. This study examine the effect of subjective spirituality on entrepreneurs' well-being by using data from the Indonesian Family Life Survey (IFLS) from 2007 to 2014. We dissect the analysis into three groups that are self-employed, business owner or employer, and employee. The result stated that spirituality does matter only for those who run the business as self-employed in terms of generating income, although they tend to have lower levels of well-being rather than those who run businesses as business owners and those who work as employees within company. We found no significant evidence that spirituality affects the well-being of business owners, on the other hand this group has the highest level of well-being. The contributions of the study are explained further in this paper.
\end{abstract}

Keywords: Entrepreneurship; Spirituality; Well-being.

JEL Classification: D10; D19; I31; J17; N3

\section{Introduction}

Spirituality will be reflected in human behavior which has potency to influence attitude in doing business or entrepreneurship. Krishnakumar and Neck (2002) stated that a work environment that facilitates employees to develop spirituality shows positive results for company performance. Spirituality helps workers to be more creative, honest and trust the organization. Pawar (2009) also mentioned the aspect of spirituality is the part of the needs of employees that must be met at work.

Since the late 1900s publishers such as The Wall Street Journal, Business Week, Fortune and others have reported an increasing trend of spirituality inside the company where employees looking for meaning and purpose in working as part of the spiritual dimension in the organization (Pawar, 2009). In line with Eckersley (2002) that conceptualized spirituality as a relationship that fosters a sense of meaning, purpose, and mission in life. Previous studies have shown that personal spiritual beliefs affect individuals in decision making (Sherman, Randall, \& Kauanui, 2015). The spirituality of an entrepreneur will influence both the way of acting and making decisions. 


\section{Wuri, Andriani, \& Utama \\ Does Spirituality Give an Impact on the Well-Being of an Entrepreneur?}

Spirituality which influence how entrepreneurs think and act, in further will give an impact on business activity as a whole such as innovation, risk management, technology, capital growth, and institutional activities (Ramadani, Dana, Ratten, \& Tahiri, 2015). Entrepreneurship is also a phenomenon of the process in which needs, goals, and aspirations are integrated (Shir, Nikolaev, \& Wincent, 2018). According to (Wiklund, Nikolaev, Shir, Foo, \& Bradley, 2019) one of the various concepts that developed to be integrated with entrepreneurship is well-being because it provides an excellent opportunity to encompass the results of entrepreneurship research broadly. Entrepreneurship encourages positive change in society as a breakthrough in commercial and social innovation that contributes to social well-being (Wiklund et al., 2019). Wellbeing is considered quite capable for representing the ideal conditions of the community, therefore entrepreneurship and well-being together become a research topic which is developed continually as a supporting aspect for practitioners in developing entrepreneurship.

Phipps (2012) also explained the relationship between spirituality and strategic leadership and shows how it influences a person in making decisions. Leadership in the context of this research is represented as entrepreneurs who take the role of leadership in their businesses.

Well-being has some definitions according to source of well-being itself. Some experts say that well-being is a positive condition of one's mentality (Deci, Olafsen, \& Ryan, 2017) and others argued that well-being is about tangible things which belong to individual. Then, the term well-being eventually was quite often associated with the terms of economic, financial, material and subjective so then it can be named as economic well-being, financial well-being, material well-being and also subjective well-being. The first of the three terms namely economic, financial and material well-being have the same purpose and they are interchangeable. While subjective well-being leads to different meaning along with measurement methods used to define it.

In general, there two points of view how to define well-being as we mention above. Firstly, scholars interpret well-being associates with psychological such as happiness, satisfaction etc. Secondly, researchers associate well-being with material such as income, expenditure, assets etc. Definition of well-being in this context refers to economic wellbeing and more associate with materialistic measurement. It was classically measured through the calculation of income, expenditure or wealth, on the other hand economists begin to put their attention to subjective well-being as a fairly relevant measure (Uy, Sun, \& Foo, 2017; Kahneman \& Krueger, 2014; Peterson \& Bush, 2013).

Therefore, it is important to explore this issue in depth in terms of the linkages of spirituality and well-being of an entrepreneur. The purpose of this study is to examine the effects of entrepreneurship and spirituality to well-being using data from the Indonesian Family Life Survey (IFLS) since 2007 until 2014. This study gives contribution both theoretically and practically. In theoretical aspect, it provides new insights related to entrepreneurship, spirituality and well-being by using IFLS data that focuses on Entrepreneurs in Indonesia. While, in practical aspect, it provides a real picture how 


\section{Wuri, Andriani, \& Utama \\ Does Spirituality Give an Impact on the Well-Being of an Entrepreneur?}

spirituality becomes substantial within individuals who associated with entrepreneurship by looking a meaning beyond the work who drive well-being.

The following section will explain the methodology employed in this study, then the third section we will discuss the result of the study, followed by the concluding remarks.

\section{Research Method}

This study employs a data survey of the Indonesian Family Life Survey (IFLS). IFLS is a household longitudinal survey in Indonesia since 1993. It represents approximately $83 \%$ of the total population in Indonesia that covers more than 30.000 individuals living in 13 of 27 provinces in 1993. The demographic distribution of data is represented by 25 provinces with multi-ethnicities and religion. We use the fourth and fifth wave of the survey that designed to stay representative of 1993 households and their descendants. The fourth wave of IFLS was fielded between late November 2007 and the end of April 2008, then the fifth wave of IFLS was fielded between late October 2014 and the end of April 2015

The personal consumption in the fifth wave was generated by using the 2014 categorical based household consumption. ${ }^{1}$ Unfortunately, only $2-3 \%$ of the household sample provides information about their personal consumption and income. The monetary unit variables in 2014 were deflated into the year base of 2007 using the annual consumer price index (CPI).

\section{Empirical Strategy}

To analyze the impact of spirituality on the well-being, we use the basic empirical model of Vial, Hanoteau, \& Prévot (2011) that studied about entrepreneurship on the household wellbeing. We run two models to simplify the economic well-being indicators that are total income and personal consumption expenditure. To capture the different of spiritual effect, we interacted the variables of entrepreneurship and spirituality.

wellbeing $_{i t}=\beta_{0}+\beta_{1}$ entrepreneurship $_{i_{t-1}}+\beta_{2}$ spirituality $_{i t}+\beta_{3}$ spiritual $*$ entrerepenur $_{i t}+\beta_{3}$ controls $_{i t}+\beta_{4}$ year $_{t}+u_{i_{t-1}}$

Variable descriptions: wellbeing $_{\text {it }}$

entrepreneurship $i_{t-1}$
: Current economic well-being measured in two indicators:

Total Income

Personal Consumption Expenditure

: One-period lag of entrepreneurship participation

\footnotetext{
${ }^{1}$ See the technical notes about personal consumption expenditure from Firmal Witoelar (2009), https://www.rand.org/well-being/social-and-behavioralpolicy/data/FLS/IFLS/download.html
} 


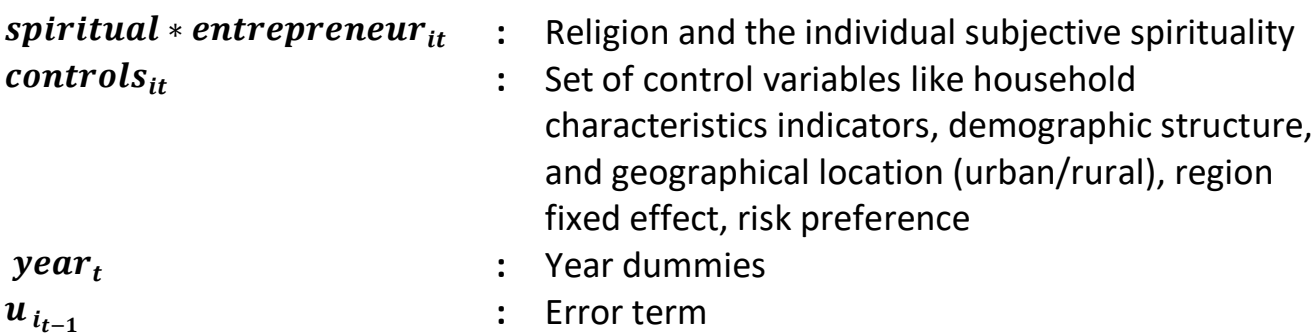

Our main hypothesis is whether the spirituality of an entrepreneur has the positive impact on the household well-being in terms of income and expenditure as a good economic measurement of well-being. We defined entrepreneurs into two categories, that are selfemployed and business owner. As mentioned in the previous studies, business owners are those who owned the business with the employee are different with those who run the business without employees (Block, Kohn, Miller, \& Ullrich, 2015; Hamilton, 2000).

We run full-sample of the individual aged 15 years old or above in the first regression to capture the different impact on the non-entrepreneur households, then we compare it with the restricted sample regression to check the consistency of the model.

\section{Summary Statistics}

Table 1 presents summary statistics from IFLS. In the 4th wave there are total of 20.163 households and 22.931 households from the last wave. In 2007 the average total income of the household is around IDR 20 million and become IDR 22 million in 2014. In 2007 the per capita expenditure is around IDR 558.000 and the nominal rose in 2014 become IDR 559.000 after deflating its value to the real value of 2007 based, but we found the declined maximum value of the monthly per capita expenditure. The education of the household head rose from 17 years on average in 2007 become 18 years in 2014 with the bigger number of household sample.

Table 1 Statistic Descriptive (a)

\begin{tabular}{|lrrrrr}
\hline \multicolumn{1}{c}{ Variables } & \multicolumn{1}{c}{ Obs } & \multicolumn{1}{c}{ Mean } & \multicolumn{1}{c}{ Std. Dev } & \multicolumn{1}{c}{ Min } & \multicolumn{1}{c}{ Max } \\
\hline Income & 20,163 & $20,665,680.7$ & $44,691,089.1$ & 0 & $2,004,999,936$ \\
Per Capita Expenditure & 19,720 & $557,984.7$ & $527,283.8$ & 27740.0 & $13,614,083$ \\
\hline Household size & 20,163 & 6.076 & 3.094 & 1 & 39 \\
\hline Age & 20,163 & 45.853 & 13.952 & 0 & 100 \\
\hline Head Education & 20,145 & 17.542 & 8.122 & 0 & 23 \\
\multicolumn{1}{c}{ Variables } & \multicolumn{1}{c}{ Obs } & Mean & Std. Dev & Min & Max \\
\hline Income & 22,931 & $22,718,186.5$ & $42,234,547.3$ & 0 & $1,520,156,416$ \\
\hline Per Capita Expenditure & 21,407 & $559,296.1$ & $496,852.5$ & 36583.7 & $11,488,368$ \\
\hline Household size & 22,931 & 6.26 & 3.30 & 1 & 40 \\
\hline Age & 22,931 & 45.10 & 13.28 & 0 & 101 \\
\hline Head Education & 22,818 & 18.58 & 7.34 & 0 & 23 \\
\hline
\end{tabular}

Source: Authors' Calculation using IFLS 4 and IFLS 5 
Wuri, Andriani, \& Utama

Does Spirituality Give an Impact on the Well-Being of an Entrepreneur?

Table 2 Statistic Descriptive (b)

\begin{tabular}{|c|c|c|c|c|c|c|}
\hline \multirow[t]{2}{*}{ Variables } & \multicolumn{3}{|c|}{2007} & \multicolumn{3}{|c|}{2014} \\
\hline & Obs & Percentage & Total obs & Obs & Percentage & Total obs \\
\hline \multicolumn{7}{|l|}{ Entrepreneurship (a) } \\
\hline Not Self-Employed $(=0)$ & 13,031 & $64.63 \%$ & \multirow[t]{2}{*}{20,163} & 14,703 & $64.12 \%$ & \multirow[t]{2}{*}{22,931} \\
\hline Self-Employment (= 1) & 7,132 & $35.37 \%$ & & 8,228 & $35.88 \%$ & \\
\hline \multicolumn{7}{|l|}{ Entrepreneurship (b) } \\
\hline Not Business Owner $(=0)$ & 19,820 & $98.30 \%$ & 20,163 & 22,466 & $97.97 \%$ & 22,931 \\
\hline Business Owner $(=1)$ & 343 & $1.70 \%$ & & 465 & 2.03 & \\
\hline \multicolumn{7}{|l|}{ Religion } \\
\hline Non-Muslim (=0) & 2,305 & $11.43 \%$ & \multirow[t]{2}{*}{20,163} & & $10.93 \%$ & 22,931 \\
\hline Muslim (=1) & 17,858 & $88.57 \%$ & & & $89.07 \%$ & \\
\hline \multicolumn{7}{|l|}{ Subjective Spirituality } \\
\hline Not Religious (= 1 ) & 534 & $2.66 \%$ & \multirow[t]{4}{*}{20,108} & 650 & $2.84 \%$ & \multirow[t]{4}{*}{22,868} \\
\hline Rather Religious (= 2) & 3,695 & $18.38 \%$ & & 4,678 & $20.46 \%$ & \\
\hline Somewhat Religious (= 3 ) & 14,629 & $72.75 \%$ & & 13,700 & $59.91 \%$ & \\
\hline Very Religious $(=4)$ & 1,250 & $6.22 \%$ & & 3,840 & $16.79 \%$ & \\
\hline \multicolumn{7}{|l|}{ Risk Preference } \\
\hline Risk Averse $(=0)$ & 8,830 & $43.95 \%$ & \multirow[t]{2}{*}{20,093} & 9,145 & $40.08 \%$ & \multirow[t]{2}{*}{22,818} \\
\hline Risk Taker $(=1)$ & 11,263 & $56.05 \%$ & & 13,673 & $59.92 \%$ & \\
\hline \multicolumn{7}{|l|}{ Head Marital Status } \\
\hline Not-Married $(=0)$ & 5,014 & $24.87 \%$ & \multirow[t]{2}{*}{20,163} & 5,144 & $22.43 \%$ & \multirow[t]{2}{*}{22,931} \\
\hline Married $(=1)$ & 15,149 & $75.13 \%$ & & 17,787 & $77.57 \%$ & \\
\hline \multicolumn{7}{|l|}{ Head Sex } \\
\hline Female $(=0)$ & 1,309 & $13.34 \%$ & \multirow[t]{2}{*}{9,814} & 1,474 & $13.29 \%$ & \multirow[t]{2}{*}{11,087} \\
\hline Male $(=1)$ & 8,505 & $86.66 \%$ & & 9,613 & $86.71 \%$ & \\
\hline \multicolumn{7}{|l|}{ Urban-Rural } \\
\hline Rural $(=0)$ & 9,905 & $49.12 \%$ & \multirow[t]{2}{*}{20,163} & 9,792 & $42.70 \%$ & \multirow[t]{2}{*}{22,931} \\
\hline Urban (= 1) & 10,258 & $50.88 \%$ & & 13,139 & $57.30 \%$ & \\
\hline \multicolumn{7}{|l|}{ Java Region } \\
\hline Non-Java Island $(=0)$ & 8,682 & $43.06 \%$ & \multirow[t]{2}{*}{20,163} & 10,640 & $46.40 \%$ & \multirow[t]{2}{*}{22,931} \\
\hline Java $(=1)$ & 11,481 & $56.94 \%$ & & 12,291 & $53.60 \%$ & \\
\hline \multicolumn{7}{|l|}{ Sumatera Region } \\
\hline Non-Sumatera Island $(=0)$ & 15,860 & $78.66 \%$ & \multirow[t]{2}{*}{20,163} & 17,558 & $76.57 \%$ & 22,931 \\
\hline Sumatera $(=1)$ & 4,303 & $21.34 \%$ & & 5,373 & $23.43 \%$ & \\
\hline
\end{tabular}

Source: Authors' Calculation using IFLS 4 and IFLS 5

The table 2 presents the dummy and categorical variables. From the 20,163 of household sample in 2007 there are $35.37 \%$ of them work as self-employment and the number went up in 2014 become $35.88 \%$ from 22,931 of household sample. Those who owned the business as employer only $1.7 \%$ of the total household sample in 2007 and rises become $2.03 \%$ in 2014. So we got the total observations who work as employee is 12,688 in 2007 and 14,238 in 2014 or $62 \%$ of the total sample between those two years.

To capture the spiritual behavior on entrepreneurship, we also use the variable of risk preference (risk averse $=0$, risk taker $=1$ ) and the subjective spirituality by four categories: not religious (1), rather religious (2), somewhat religious (3), and very religious (4). For the risk preference, the sample shows that there are greater number of the household member who are risk taker rather than risk averse.

To capture the geographical fixed effect, we consider the effect of whether the household live in urban or rural area. There $50.88 \%$ of household sample live in urban area in 2007 
Does Spirituality Give an Impact on the Well-Being of an Entrepreneur?

and more in 2014 for $57.30 \%$. Furthermore, $53 \%-57 \%$ of the sample live Java island and $21-24 \%$ live in Sumatera.

\section{Correlation Matrix}

We present correlation matrix of main variables in table 5 (see appendix). Unfortunately, we do not find the significant correlation between spirituality on both economic wellbeing indicators, nor with the dummy variables of entrepreneurship (self-employed and business owner). But for risk preference variable, we found the positive significant correlation with income and per capita expenditure as economic well-being indicators. It also has the negative significant correlation with spirituality.

We also note that dummy of self-employed negatively correlated with the economic wellbeing and risk preference. It is different with the dummy of business owner that correlates positively with the economic well-being indicators and risk preference.

\section{Result and Discussion}

Table 3 Full Sample Regression - The Impact of Entrepreneur's Spirituality on the Household Well-Being

\begin{tabular}{|c|c|c|c|c|}
\hline \multirow[t]{2}{*}{ VARIABLES } & \multicolumn{2}{|c|}{ Income (1a) } & \multicolumn{2}{|c|}{$\begin{array}{l}\text { Per Capita Expenditure } \\
\qquad(1 \mathrm{~b})\end{array}$} \\
\hline & Coefficient & $S E$ & Coefficient & SE \\
\hline \multicolumn{5}{|l|}{ Subjective Spirituality } \\
\hline $\begin{array}{l}\text { (1 = Not Religious, } 2 \text { = Rather Religious, } 3= \\
\text { Somewhat Religious, } 4 \text { = Very Religious) }\end{array}$ & 0.0109 & $(0.0122)$ & 0.00315 & $(0.00724)$ \\
\hline Self-Employed (Self-Employed = 1) & $-0.465 * * *$ & (0.0473) & $-0.0833 * * *$ & $(0.0285)$ \\
\hline Business Owner (Business Owner = 1) & $0.534 * *$ & $(0.222)$ & $0.621 * * *$ & (0.133) \\
\hline Self-Employed*Subjective Spirituality & $0.240 * * *$ & (0.0490) & 0.0429 & (0.0295) \\
\hline Business Owner*Subjective Spirituality & -0.0332 & (0.0749) & -0.0529 & (0.0449) \\
\hline Risk Taker (Risk Taker $=1$, Risk Averse $=0$ ) & $0.163 * * *$ & $(0.0153)$ & $0.0831 * * *$ & $(0.00906)$ \\
\hline Islam (Islam = 1, Non-Islam =0) & $-0.196 * * *$ & $(0.0342)$ & $-0.218 * * *$ & $(0.0208)$ \\
\hline \multicolumn{5}{|c|}{ Household Characters } \\
\hline Number of Household Member & $0.0921 * * *$ & $(0.00273)$ & $-0.0512 * * *$ & $(0.00162)$ \\
\hline $\begin{array}{l}\text { Marital Status (Married = 1, Unmarried = } \\
\text { 0) }\end{array}$ & $0.164 * * *$ & $(0.0265)$ & $-0.378 * * *$ & $(0.0155)$ \\
\hline Year of Education & $0.0237^{* * *}$ & $(0.00105)$ & $0.0132 * * *$ & $(0.000615)$ \\
\hline Age & $0.00290 * * *$ & (0.000678) & $0.00159 * * *$ & (0.000399) \\
\hline Gender (Male $=1$, Female $=0$ ) & $0.288 * * *$ & $(0.0287)$ & $0.0600 * * *$ & $(0.0167)$ \\
\hline \multicolumn{5}{|c|}{ Geographical Effect } \\
\hline Urban (Urban = 1, Rural =0) & $0.434 * * *$ & (0.0159) & $0.283^{* * *}$ & (0.00944) \\
\hline Java (Java = 1, Non-Java =0) & -0.0283 & (0.0196) & -0.00959 & $(0.0117)$ \\
\hline $\begin{array}{l}\text { Sumatera (Sumatera }=1 \text {, Non-Sumatera }= \\
\text { 0) }\end{array}$ & $0.106 * * *$ & $(0.0228)$ & $0.0507^{* * *}$ & $(0.0136)$ \\
\hline Year & $0.0657 * * *$ & $(0.0150)$ & $0.0189 * *$ & (0.00887) \\
\hline Constant & $14.64 * * *$ & (0.0639) & $13.27 * * *$ & (0.0379) \\
\hline Observations & \multicolumn{2}{|c|}{19,670} & \multicolumn{2}{|c|}{19,873} \\
\hline Number of Year & \multicolumn{2}{|c|}{2} & \multicolumn{2}{|c|}{2} \\
\hline
\end{tabular}

Source: Authors' Calculation using IFLS 4 and IFLS 5 


\section{Wuri, Andriani, \& Utama \\ Does Spirituality Give an Impact on the Well-Being of an Entrepreneur?}

Table 3 presents the full sample regression of the two economic well-being measurement models. In these regressions, we employed all the household samples who are selfemployed, business owners, and employees (not run the business). To capture the specific effect of an entrepreneur's spirituality on his/her well-being, we interacted subjective spirituality with the dummy variables of self-employed and business owners.

From the result we do not find the strong evidence to reject our null hypothesis that subjective spirituality statistically significant to affect the household total income nor per capita consumption expenditure, but if we capture it with the specific variable of selfemployed, it has a positive significant effect on the income, but we do not find significant evidence on the per capita expenditure. We also found no significant evidence to reject our $\mathrm{HO}$ on business owner subjective spirituality. By this regression we only find strong evidence to reject $\mathrm{HO}$ only for self-employed subjective spirituality by 0.240 coefficient. Those who have stronger spirituality and run the self-employing business is likely to have a better income, but we need to be careful in interpreting this interaction variable since self-employed has a negatively significant effect on income and per capita expenditure. If we calculate the net-effect of self-employed subjective spirituality, we still get the negative value $(0.240-0.465=0.225)$, so it means that even with the higher level of subjective spirituality, they still have a lower level of well-being in terms of total income by $22,5 \%$.

We also did not find that risk preference nor religion and spirituality have an impact to generate household income. On the other hand, there is a statistically significant impact of religion to per capita consumption expenditure. Muslim population of the sample are likely to have $28,2 \%$ less of income and $22,5 \%$ less per capita consumption expenditure.

Another spirituality control variable such as risk preference and religion were found to be significant in influencing subjective well-being for both measures of subjective well-being. Those who have a higher risk-preference tend to have higher well-being in both well-being measures. Whereas if we compare the embrace of religion, those who embrace Islam tend to have lower well-being than non-Muslims. This can be caused by the number of samples that are mostly Muslim (88, 57\% in 2007 and $89.04 \%$ in 2014).

Table 4 presents the regression result with the restricted sample only those who run businesses both as self-employed and business owners who show the same results as fullsample regression where subjective spirituality is found to be insignificant in influencing both kinds of well-being measurement. Whereas if subjective spirituality is interacted with self-employed variables, subjective spirituality shows a significant influence in influencing income but with a lower level of significance ( $90 \%$ level of significant).

Likewise, those who are risk-takers tend to be more prosperous in terms of generating income and in terms of per capita expenditure. While religious variable is only significant in regression per capita expenditure with the opposite sign.

From the household characteristics control variables, we find that the number of the household member has a contribution to the household income and per capita 
Does Spirituality Give an Impact on the Well-Being of an Entrepreneur?

Table 4 Restricted Sample Regression

\begin{tabular}{|c|c|c|c|c|}
\hline \multirow[t]{2}{*}{ VARIABLES } & \multicolumn{2}{|c|}{ Income (2a) } & \multicolumn{2}{|c|}{$\begin{array}{l}\text { Personal Consumption } \\
\text { Expenditure (2b) }\end{array}$} \\
\hline & Coefficient & $S E$ & Coefficient & SE \\
\hline \multicolumn{5}{|l|}{ Subjective Spirituality } \\
\hline $\begin{array}{l}\text { (1 = Not Religious, } 2 \text { = Rather Religious, } 3= \\
\text { Somewhat Religious, } 4 \text { = Very Religious) }\end{array}$ & 0.00850 & $(0.0195)$ & 0.00641 & (0.0107) \\
\hline $\begin{array}{l}\text { Self-Employed } \\
(\text { Self-Employed }=1 \text {, Business Owner }=0 \text { ) }\end{array}$ & $-0.928 * * *$ & $(0.145)$ & $-0.612 * * *$ & $(0.0844)$ \\
\hline Self-Employed*Subjective Spirituality & $0.256^{*}$ & $(0.155)$ & 0.0942 & (0.0895) \\
\hline Risk Taker (Risk Taker $=1$, Risk Averse $=0$ ) & $0.137 * * *$ & $(0.0236)$ & $0.0713^{* * *}$ & (0.0130) \\
\hline Islam (Islam = 1, Non-Islam =0) & -0.216 & (0.150) & $-0.269 * * *$ & $(0.0871)$ \\
\hline \multicolumn{5}{|c|}{ Household Characters } \\
\hline Number of Household Member & $0.108 * * *$ & $(0.00404)$ & $-0.0395 * * *$ & $(0.00224)$ \\
\hline Marital Status (Married $=1$, Unmarried $=0$ ) & $0.117^{* *}$ & $(0.0466)$ & $-0.277^{* * *}$ & $(0.0250)$ \\
\hline Year of Education & $0.0172 * * *$ & $(0.00147)$ & $0.00876^{* * *}$ & $(0.000810)$ \\
\hline Age & -0.00122 & (0.000977) & $0.00169 * * *$ & (0.000535) \\
\hline Gender (Male $=1$, Female $=0$ ) & $0.290 * * *$ & $(0.0465)$ & 0.0244 & $(0.0248)$ \\
\hline \multicolumn{5}{|c|}{ Geographical Effect } \\
\hline Urban (Urban = 1, Rural =0) & $0.436 * * *$ & $(0.0245)$ & $0.290 * * *$ & (0.0135) \\
\hline Java $(\operatorname{Java}=1$, Non-Java $=0)$ & -0.0166 & (0.0299) & 0.00687 & (0.0166) \\
\hline $\begin{array}{l}\text { Sumatera (Sumatera }=1 \text {, Non-Sumatera }= \\
\text { 0) }\end{array}$ & $0.121 * * *$ & $(0.0336)$ & $0.0847^{* * *}$ & $(0.0187)$ \\
\hline Year & $0.109 * * *$ & (0.0234) & $0.0390 * * *$ & (0.0129) \\
\hline Constant & $15.34 * * *$ & (0.167) & $13.71 * * *$ & (0.0954) \\
\hline Observations & \multicolumn{2}{|c|}{9,167} & \multicolumn{2}{|c|}{9,401} \\
\hline Number of Year & \multicolumn{2}{|c|}{2} & \multicolumn{2}{|c|}{2} \\
\hline
\end{tabular}

Source: Authors' Calculation using IFLS 4 and IFLS 5

expenditure. It is statistically significant at the $99 \%$ level of significance to say that household size has an effect on household well-being. When the household has one more member, it would likely generate more income for about 9-10 percentage points. At the same time, the one additional household also generates smaller per capita consumption expenditure by 4-5 percentage points, hold the other factors constant.

Marital status is significant in both regressions with the positive sign on income and the negative sign on per capita expenditure. It is statistically significant that married individuals tend to have less per capita consumption expenditure by $28 \%-38 \%$ and higher income by $12-16 \%$, holding others remain. Education also has a positive impact on both measurements of well-being. One year more education will lead to $2.4 \%$ higher income and $1.3 \%$ higher amount of per capita consumption expenditure. The magnitude of impact is less for those who run a business both as self-employed and as a business owner.

The capture of geographical fixed effect we also found that households in urban area have the better well-being in terms of income and per capita consumption. Those who live in Sumatera tend to have higher level of well-being in both measurements.

Based on the estimation, we find that self-employed individuals tend to have less capacity to generate income rather than those who run the business as business owners and those who work in employment. Whereas those who run businesses as business owners are the most prosperous group. This proves that business owners have more ability because they 


\section{Wuri, Andriani, \& Utama \\ Does Spirituality Give an Impact on the Well-Being of an Entrepreneur?}

are already in a more developed stage of business because they already have employees even though they have fewer numbers (1.7-2\% of the total sample). The groups that have the lowest welfare level are those who run small-scale businesses by relying on their own workforce. Most of the self-employment jobs in Indonesia are dominated by smallmedium enterprises (SMEs) rather than big established companies.

Kwon \& Sohn (2017) construct the model to measure the job satisfaction in selfemployment (using IFLS). IFLS ques: "Response to the following question on a scale of 1 to 4: how satisfied are you with your current job?" as dependent variable. They found a statistically significant indicator for job dissatisfaction of self-employed rather than work as employee. It strengthen our argument that starting a small business as self-employed still a second career choice in Indonesia. There still low incentive to start the business in Indonesia. On the other side, business is also a promising sector if the business can grow so that their ability to generate income is higher than those who work as employees in the company.

This is why spirituality only matters in the group that runs the business as self-employed in relation to the amount of risk they face in running the business. At least those who have a higher level of spirituality will be more courageous in making risky business decisions but have the potential to develop more.

\section{Conclusion}

The main goal of this paper is to investigate the effect of spirituality on the economic wellbeing. We find that there is a significant effect of spirituality toward well-being of selfemployed, but it is still lower compared to other groups of business owners and employees. However, spirituality does not have significant effect toward business owners. Thus, we conclude it is due to the higher risk they face in running a business, subjective spirituality matter for those who start the business especially for being self-employed.

There are several limitations in this study and might be an opportunity for future research improvement. First, research used a theoretical umbrella that is self-determination theory to explain the framework, while in the framework only intrinsic factors are included as moderating variables, so it is better in the next studies to include extrinsic factors such as economic development, ethnicity, social conditions and so on. Second, the study used secondary data is IFLS in 2007 - 2014, so in terms of the novelty of the data less representative of the current condition because the available data has not been updated. Third, in order to capture more precise analysis, it is better to expand the analysis to subjective well-being with a more objective measure of spirituality.

\section{Acknowledgment}

We would like to thank the Rocky Adiguna, Ph.D. and Think Indonesia for his research assistance and supportive encouragement. 
Wuri, Andriani, \& Utama

Does Spirituality Give an Impact on the Well-Being of an Entrepreneur?

Appendix

Table 5 Correlation Matrix

\begin{tabular}{|c|c|c|c|c|c|c|c|c|c|c|c|c|c|c|c|}
\hline Variables & (1) & (2) & (3) & (4) & (5) & (6) & (7) & (8) & (9) & (10) & (11) & (12) & (13) & (14) & (15) \\
\hline (1) Total income & 1.000 & & & & & & & & & & & & & & \\
\hline \multirow[t]{2}{*}{ (2) Pce } & 0.211 & 1.000 & & & & & & & & & & & & & \\
\hline & $(0.000)$ & & & & & & & & & & & & & & \\
\hline \multirow[t]{2}{*}{ (3) Spirituality } & 0.008 & -0.010 & 1.000 & & & & & & & & & & & & \\
\hline & (0.309) & $(0.236)$ & & & & & & & & & & & & & \\
\hline \multirow[t]{2}{*}{ (4) Risk taker } & 0.052 & 0.073 & -0.028 & 1.000 & & & & & & & & & & & \\
\hline & $(0.000)$ & $(0.000)$ & $(0.000)$ & & & & & & & & & & & & \\
\hline \multirow[t]{2}{*}{ (5) Muslim } & -0.018 & -0.065 & -0.119 & 0.012 & 1.000 & & & & & & & & & & \\
\hline & $(0.022)$ & $(0.000)$ & $(0.000)$ & (0.134) & & & & & & & & & & & \\
\hline \multirow[t]{2}{*}{ (6) Self employed } & -0.127 & -0.201 & 0.008 & -0.066 & 0.016 & 1.000 & & & & & & & & & \\
\hline & $(0.000)$ & $(0.000)$ & $(0.297)$ & $(0.000)$ & $(0.040)$ & & & & & & & & & & \\
\hline \multirow[t]{2}{*}{ (7) Entrepreneur } & 0.127 & 0.201 & -0.008 & 0.066 & -0.016 & -1.000 & 1.000 & & & & & & & & \\
\hline & $(0.000)$ & $(0.000)$ & (0.297) & $(0.000)$ & $(0.040)$ & $(1.000)$ & & & & & & & & & \\
\hline \multirow[t]{2}{*}{ (8) Household size } & 0.156 & -0.133 & 0.035 & -0.013 & -0.017 & -0.003 & 0.003 & 1.000 & & & & & & & \\
\hline & $(0.000)$ & $(0.000)$ & $(0.000)$ & $(0.092)$ & $(0.035)$ & (0.696) & (0.696) & & & & & & & & \\
\hline \multirow[t]{2}{*}{ (9) Marital status } & 0.020 & -0.088 & 0.015 & 0.021 & 0.022 & -0.027 & 0.027 & -0.071 & 1.000 & & & & & & \\
\hline & (0.013) & $(0.000)$ & $(0.060)$ & $(0.006)$ & $(0.005)$ & $(0.001)$ & $(0.001)$ & $(0.000)$ & & & & & & & \\
\hline \multirow[t]{2}{*}{ (10) Education } & 0.078 & 0.117 & -0.036 & 0.101 & 0.007 & -0.092 & 0.092 & -0.058 & 0.118 & 1.000 & & & & & \\
\hline & $(0.000)$ & $(0.000)$ & $(0.000)$ & $(0.000)$ & $(0.362)$ & $(0.000)$ & $(0.000)$ & $(0.000)$ & $(0.000)$ & & & & & & \\
\hline \multirow[t]{2}{*}{ (11) Head age } & 0.013 & -0.046 & 0.119 & -0.061 & -0.034 & 0.047 & -0.047 & 0.269 & -0.178 & -0.256 & 1.000 & & & & \\
\hline & (0.099) & $(0.000)$ & $(0.000)$ & $(0.000)$ & $(0.000)$ & $(0.000)$ & $(0.000)$ & $(0.000)$ & $(0.000)$ & $(0.000)$ & & & & & \\
\hline \multirow[t]{2}{*}{ (12) Gender } & 0.029 & -0.083 & -0.053 & 0.061 & 0.011 & -0.035 & 0.035 & 0.004 & 0.700 & 0.154 & -0.160 & 1.000 & & & \\
\hline & $(0.004)$ & $(0.000)$ & $(0.000)$ & $(0.000)$ & $(0.288)$ & $(0.001)$ & $(0.001)$ & $(0.671)$ & $(0.000)$ & $(0.000)$ & $(0.000)$ & & & & \\
\hline \multirow[t]{2}{*}{ (13) Java } & -0.008 & 0.024 & 0.021 & 0.009 & 0.259 & -0.038 & 0.038 & -0.073 & -0.012 & 0.050 & 0.093 & -0.044 & 1.000 & & \\
\hline & $(0.306)$ & $(0.003)$ & (0.009) & $(0.267)$ & $(0.000)$ & $(0.000)$ & $(0.000)$ & $(0.000)$ & $(0.138)$ & $(0.000)$ & $(0.000)$ & $(0.000)$ & & & \\
\hline \multirow[t]{2}{*}{ (14) Sumatera } & 0.009 & 0.013 & -0.153 & 0.008 & -0.055 & 0.022 & -0.022 & 0.063 & 0.003 & 0.026 & -0.070 & 0.029 & -0.587 & 1.000 & \\
\hline & $(0.247)$ & (0.095) & $(0.000)$ & $(0.301)$ & $(0.000)$ & $(0.005)$ & $(0.005)$ & $(0.000)$ & (0.731) & $(0.001)$ & $(0.000)$ & (0.004) & $(0.000)$ & & \\
\hline \multirow[t]{2}{*}{ (15) Urban } & 0.106 & 0.199 & -0.035 & 0.074 & 0.040 & -0.101 & 0.101 & 0.038 & -0.043 & 0.173 & -0.012 & -0.047 & 0.163 & -0.114 & 1.000 \\
\hline & $(0.000)$ & $(0.000)$ & $(0.000)$ & $(0.000)$ & $(0.000)$ & $(0.000)$ & $(0.000)$ & $(0.000)$ & $(0.000)$ & $(0.000)$ & $(0.112)$ & $(0.000)$ & $(0.000)$ & $(0.000)$ & \\
\hline
\end{tabular}




\section{Wuri, Andriani, \& Utama \\ Does Spirituality Give an Impact on the Well-Being of an Entrepreneur?}

\section{References}

Block, J. H., Kohn, K., Miller, D., \& Ullrich, K. (2015). Necessity Entrepreneurship and Competitive Strategy. Small Business Economics, 44(1), 37-54.

https://doi.org/10.1007/s11187-014-9589-x

Deci, E. L., Olafsen, A. H., \& Ryan, R. M. (2017). Self-Determination Theory in Work Organizations: The State of a Science. Annual Review of Organizational Psychology and Organizational Behavior, 4(1), 19-43. https://doi.org/10.1146/annurev-orgpsych$\underline{032516-113108}$

Eckersley, R. (2002). Spirituality, Progress, Meaning and Values: Implications for Leadership and Management. Journal of Spirituality, Leadership and Management, 1, 15-28.

Hamilton, B. H. (2000). Does Entrepreneurship Pay? An Empirical Analysis of the Returns to Self-Employment. Journal of Political Economy, Vol. 108, pp. 604-631. https://doi.org/10.1086/262131

Kahneman, D., \& Krueger, A. B. (2014). Developments in the Measurement of Subjective Well-Being. The Journal of Economic Perspectives, 20(1), 3-24. Retrieved from https://pubs.aeaweb.org/doi/pdfplus/10.1257/089533006776526030

Krishnakumar, S., \& Neck, C. P. (2002). The "What", 'Why" and "How"' of Spirituality in the Workplace."'” Journal of Managerial Psychology, 17(3), 153-164. https://doi.org/10.1108/02683940210423060

Kwon, I., \& Sohn, K. (2017). Job Dissatisfaction of the Self-Employed in Indonesia. Small Business Economics, 49(1), 233-249. https://doi.org/10.1007/s11187-016-9820-z

Pawar, B. S. (2009). Workplace spirituality facilitation: A comprehensive model. Journal of Business Ethics, 90(3), 375-386. https://doi.org/10.1007/s10551-009-0047-7

Peterson, G. W., \& Bush, K. R. (2013). Handbook of marriage and the family: Third edition. In Handbook of Marriage and the Family: Third Edition. https://doi.org/10.1007/978-14614-3987-5

Phipps, K. A. (2012). Spirituality and Strategic Leadership: The Influence of Spiritual Beliefs on Strategic Decision Making. Journal of Business Ethics, 106(2), 177-189. https://doi.org/10.1007/s10551-011-0988-5

Ramadani, V., Dana, L. P., Ratten, V., \& Tahiri, S. (2015). The Context of Islamic Entrepreneurship and Business: Concept, Principles and Perspectives. International Journal of Business and Globalisation, 15(3), 244. https://doi.org/10.1504/ijbg.2015.071906

Sherman, C. L., Randall, C., \& Kauanui, S. K. (2015). Are You Happy Yet? Entrepreneurs' Subjective Well-Being. Journal of Management, Spirituality and Religion. https://doi.org/10.1080/14766086.2015.1043575

Shir, N., Nikolaev, B. N., \& Wincent, J. (2018). Entrepreneurship and well-being: The role of psychological autonomy, competence, and relatedness. Journal of Business Venturing, 34(5), 105875. https://doi.org/10.1016/j.jbusvent.2018.05.002

Uy, M. A., Sun, S., \& Foo, M. Der. (2017). Affect Spin, Entrepreneurs' Well-Being, and Venture Goal Progress: The Moderating Role of Goal Orientation. Journal of Business Venturing, 32(4), 443-460. https://doi.org/10.1016/j.jbusvent.2016.12.001

Vial, V., Hanoteau, J., \& Prévot, F. (2011). Does Entrepreneurship Improve Economic WellBeing? Frontiers of Entrepreneurship Research, 31(4).

Wiklund, J., Nikolaev, B., Shir, N., Foo, M., \& Bradley, S. (2019). Entrepreneurship and wellbeing: Past, present , and future. Journal of Business Venturing, 34(4), 579-588.

https://doi.org/10.1016/j.jbusvent.2019.01.002 